\title{
Aligning Complementary Funding Opportunities - through TAS - the Smart Answer to the Challenges of Industry 4.0 Transformation
}

\author{
Eugen-Silviu VRĂJITORU \\ Transilvania University of Brasov, Romania, eugen.vrajitoru@unitbv.ro \\ Mircea BOȘCOIANU \\ Transilvania University of Brasov, Romania, boscoianu.mircea@yahoo.com \\ Elena-Corina BOȘCOIANU \\ „INCAS” Bucharest, Romania, boscoianu.corina@incas.ro
}

\begin{abstract}
Industry 4.0 transformation is an opportunity that needs to be carefully considered in a different way in emerging markets. The opportunity aims to reduce the gap with developed markets through the link of democratizing the elements of innovation (organizational and transformational technique). Although new funding programs have emerged, accessibility to funding for priority directions and for locations and regions of interest is only slightly related to expectations. Thus, the concept of complementary financing is proposed and alternative solutions and strategies based on the triple alternative assets - (venture capital and private equity funds), alternative strategies - (hedge funds adapted for emerging markets) and alternative partnerships (public - private partnerships) are identified. The proposed innovative idea is based on capturing the synergies between the three elements of the mentioned triplet and the ability to quickly connect to the financing flow through major programs (NRFF, H2020, NGD). The challenge refers to the reduced functionality of the Romanian capital market, the proposal aiming at practical solutions for creating the adequate complementary financing framework in relation to the real priorities, their dynamics but also the national strategy for reducing local and regional disparities in Romania. The idea is innovative, through modularity and scalability gives real integration capabilities in practice. It also provides an adequate response to the case of low functionality offered by emerging capital markets. In this case the special purpose vehicle SPV is represented by a special dedicated hedge fund with rotating sub-portfolios.
\end{abstract}

\section{Keywords}

complementary funding, Industry 4.0 transformation, venture capital funds VCFs, private equity funds PEFs, hedge funds HFs

\section{Introduction}

Defining the concept of Industry 4.0 starts from understanding the evolutions and implications of previous industrial revolutions. The industrial revolution is the complex process of radical transformation of technologies, which results in essential changes in economic, social and cultural structures. Toffler proposes a set of developments based on the emergence of machines, the transition to industry and technical innovations, the transition to the knowledge-based society [1], while Bell highlights the paradigms of transport development, development and implementation of electrification, the emergence of electronic devices and circuits respectively of the IT and automation industry [1]. The continuous acceleration of industrial technological innovations is essential in the dynamics of industrial developments. The dynamics of the evolution of industrial technologies involve on the one hand new infrastructures and new qualifications for specialists in the industrial field, and on the other hand new business models and new solutions for their financing.

The first industrial revolution ("Industry 1.0") is based on the introduction of steam engines, as the first generation of cars and the invention of the mechanical computer (Charles Babbage) [1], having an impact on changing the structure of society, the process of urbanization and the emergence of new skills.

The second industrial revolution, "Industry 2.0.", is related to: electricity production and distribution systems, chemicals, railways, qualitative refining of products made of high-quality steel, automobile, aircraft, radio, telegraph, and respectively the emergence of mass production. Industry 2.0 has increased work efficiency and the standard of living of the population. 
The third industrial revolution, called "Industry 3.0", started from the following paradigms: profit capture starting from the development and design stages, increasing force efficiency by integrating robots and increasing the automation of production processes; radical change of business models (with digitized models); globalization (accelerated by digital technologies) of all processes. There is also a change in the structure of energy use (increasing the share of nuclear energy), the development of mobile telephony (3G) with video facilities, computers and the democratization of internet use.

The fourth industrial revolution, "Industry 4.0", integrates artificial intelligence (AI), robotics, quantum computing, BDA (big data analysis), VR / AR virtual / augmented reality, 5G technology, 3D printing, IoT (internet of Things). CPS (cyber physical systems) have been integrated, which have leveraged digital technologies for efficient interconnections (between machines, assembly lines, and entire factories). Industry 4.0 differs from previous industrial revolutions by: eliminating human labor from production processes (and thus eliminating human error with the help of artificial intelligence, obtaining quasi-optimal processes; global interconnection of companies in real time; increasing job security and reducing negative social consequences, increasing the effectiveness of IPR (intellectual property rights) protection, unique capabilities for rapid production change. This results in new design requirements: transparency of information and increased process efficiency; increasing interoperability and reducing information communication errors by developing communication between sensors, people, machines and various devices; decentralized decision-making through intelligent machines and superior collaborative capabilities; increasing the efficiency of technical assistance. Industry 4.0 offers new solutions for the growth and development of the knowledge economy, which includes innovative development, increasing the living standards of the population and the development of science and education. There is a reduction in production costs through extensive automation; reduction of waste resulting from the production process; increasing work intensity through new areas of interest and increasing the level of qualification. Industry 4.0 ensures the efficient transition to a new economic reality by increasing the quality and differentiation of products and services, democratizing accessibility through digital globalization, increasing the demands on the environment. From here results the increase of revenues and consumption, respectively the increase of the profit of the new digitized companies [1 - 5].

\section{Identifying Smart Financing Lines through the Link of Major Programs}

Starting from the opportunities offered by Industry 4.0, there is the problem of how to access smart financing projects through the link of major programs (NRFF, H2020, NGD). For example, NRFF offers limited development opportunities because the targeted sectors do not necessarily involve only Industry 4.0 technologies to a small extent. This raises the issue of using complementary funding structures that could be targeted on the one hand on projects in disadvantaged areas or in areas that are not representative in the case of major funding programs. For example, in the case of technological SMEs, there is on the one hand a particular interest in supporting these financings, although in the major financing programs the participation in this type of financing is low. Thus, multi-disciplinary research is required for understanding the relationship and connections between technological entrepreneurship and innovation. The interest is even higher for the case of regional entrepreneurship and highlights a possible move to the top area of innovation and through this mechanism highlights a possible change or even transformation of the competitiveness landscape in Romania. The Schumpeterian paradigm of creative destruction highlights the need for multidimensional radical change. Later, however, the role of latent and emerging entrepreneurship LEE in accelerating innovation to markets (Audretsch, 2017; Autio, 2014; Caiazza, 2015; Neffke, 2018) is highlighted and through this understanding of the effects of local drivers on innovation (Balland, 2015) and respectively the harmonization between the elements of local / regional policies and respectively national policies for a better support of top innovative entrepreneurial business [6 - 9].

This results in particularly important consequences for reducing Romania's regional disparities. Also, in the context of Industry 4.0, new managerial models for innovation and entrepreneurship dedicated for emerging markets are highlighted. Thus, the problem of flexible adaptation through dynamic capabilities and the integration of financing aspects is noticeable, a branch of literature still 
RECENT, Vol. 22, no. 1(63), 2021

undeclared with implications not only on the development of technological companies but also on the possibility of launching new firms. Here can be integrated various implications on entrepreneurial culture (Stutzer, 2014), or entrepreneurial orientation (Wiklund \& Shepherd, 2005) mixed with entrepreneurial cognition and opportunities, with possible implications on the future design of technological entrepreneurial policies (Shane, 2009), and the whole technological entrepreneurial ecosystems (Belitski, 2017). These were just a few arguments for the detailed analysis of complementary financing possibilities with applications in the case of technological enterprises in emerging markets [10 - 13].

Figure 1 describes a representation of the complementary financing solutions and strategies for an innovative proposal dedicated to the case of Romania. Although the funds attracted through major project programs are consistent, there are implementation problems specific to our country (insufficient preparation of project proposals, lack of experience of project managers, insufficient representation of innovative project proposals) and emerging countries (macroeconomic conditions of rough implementation, insufficient understanding by the authorities of the importance of reducing local and regional disparities through the link of innovation, reduced capacity to carry out projects in normal times, totally inadequate possibilities to carry out projects in conditions of crisis and turbulence)[10].

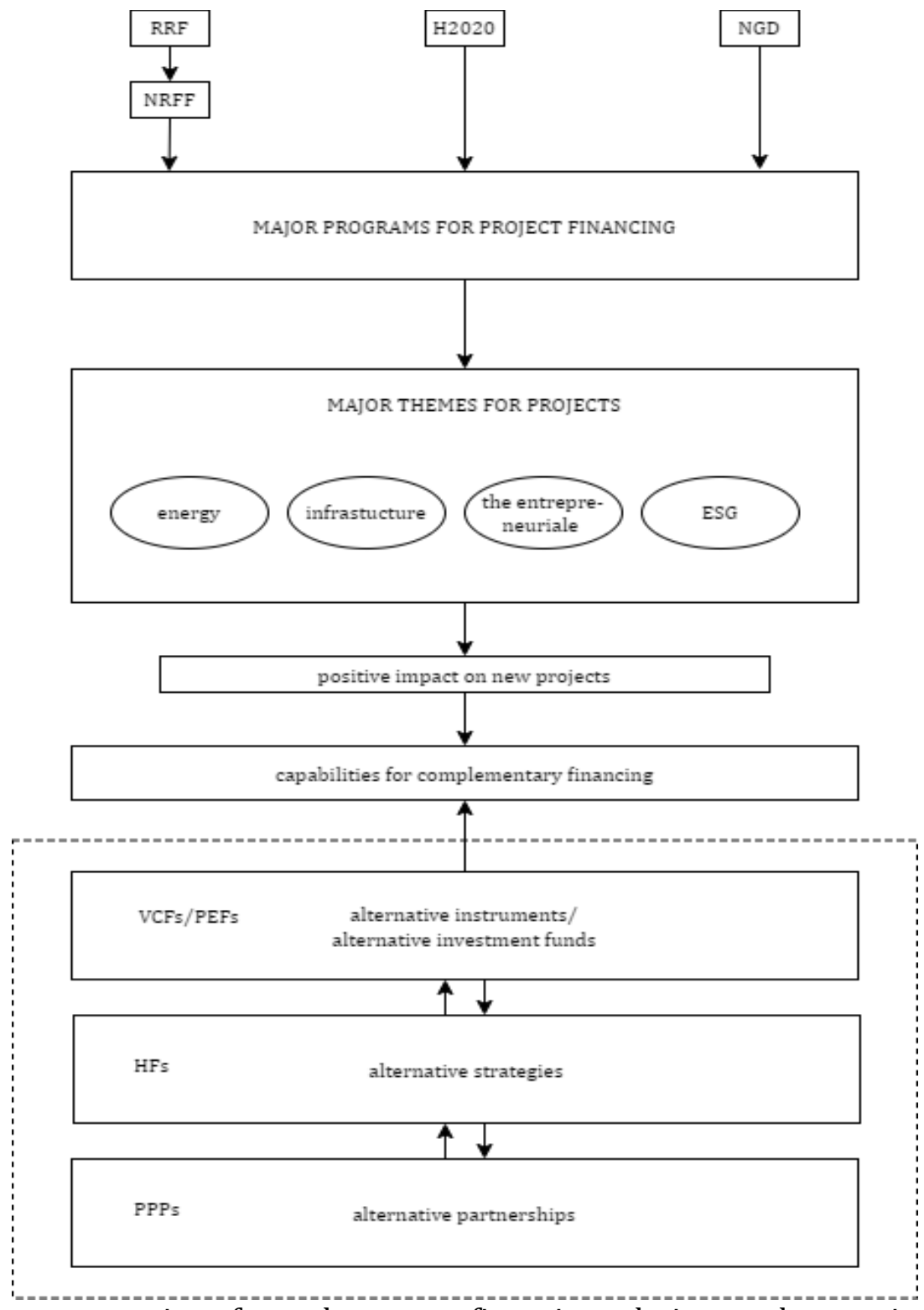

Fig. 1. A representation of complementary financing solutions and strategies for Romania 


\section{Highlighting the Possibilities for Complementary Financing - through TAS}

TAS (Triple Alternative Synergy) is a metaphor for complementary financing in the case of emerging markets, which takes into account a triplet of alternatives (Instruments-Strategies-Partnerships / architectural relationships) $[10,14,15,16]$. TAS is not only an innovative concept proposed in this paper but also a practical way that offers effective concrete possibilities to achieve the desideratum of complementary financing in emerging markets. The first step of research refers to the development of solutions and strategies for the development of instruments for alternative financing in the form of alternative investment funds (AIFs). In this case it is possible to consider special purpose vehicles (SPVs) like Venture Capital Funds (VCFs) or Private Equity Funds (PEFs). This first pillar is dedicated for consolidation of capabilities to implement conventional alternative instruments to boost performance through intelligent and competitive project allocations, but dedicated for emerging markets [17]. The diversification of VCFs / PEFs portfolios should be focused on flexible allocations and the efficiency is associated with markets, liquidity and informational costs. In the second stage of research, we integrate different alternative strategies and the resulting product is expressed by Hedge Funds (HFs). Although in developed markets HFs are popular and well known, these vehicles represent a unique aspect for the Romanian capital market. HFs are investment vehicles that incorporate flexible leverage mixed with lower correlation with conventional assets, but in the case of the Romanian capital market there are implementation difficulties due to the lack of short-sales and leverage possibilities. Thus, innovative solutions based on other strategic principles must be identified. We suggest an absolutely new innovative flexible architecture based on the principles of satellite sub-portfolio rotation. A unique mechanism is created to make the architectures of these HFs more flexible in order to compensate for the lack of market instruments through innovative solutions. Thirdly, other strategic solutions and schemes based on the realization of public-private partnerships (PPPs) that can contribute to flexible adaptation in inefficient markets can be considered.

\section{Conclusions and Contributions}

The industrial revolutions represented qualitative leaps with an impact on the growth of economic well-being and having a social and cultural impact of amplifying the effects. Industrial dynamics and the evolution of IoT have allowed a set of synergistic processes: large-scale automation and the possibility of concluding global business contracts, superior access to diversified and customized products, development of intelligent organizations (beyond intelligent business there also exist intelligent cities, intelligent supply chain, intelligent transportation), a better protection via cybersecurity, with impact on multidimensional transformation.

The complementary financing schemes are very important in the actual context of markets development because and because the technology and innovation disruption is not fully understanded this new branch of literature is emerging. The importance of complementary financing in the cases of emerging markets was shown and the case of technological entrepreneurship was exemplified. It also highlights the TAS (triple alternative synergy) proposal based on the triplet of alternatives and justified the viability of this innovative and scalable solution for the Romanian capital market.

\section{References}

1. Popkova E.G., Ragulina Y.V., Bogoviz A.V. (Eds.) (2019): Industry 4.0: Industrial Revolution of the 21st Century. Springer International Publishing, ISBN 978-3-319-94309-1, e-ISBN 978-3-319-94310-7, Series „Studies in Systems, Decision and Control", ISSN 2198-4182, Vol. 169, DOI: 10.1007/978-3-319-94310-7

2. Sudip M., Chandana R., Anandarup M. (2021): Introduction to Industrial Internet of Things and Industry 4.0. CRC Press, ISBN 9780367897581, e-ISBN 9781003020905, https://doi.org/10.1201/9781003020905

3. Kumar K., Zindani D., Davim J.P. (2019): Industry 4.0: Developments towards the Fourth Industrial Revolution. Springer Verlag, Singapore, ISBN10: 981138164X; ISBN 9789811381645

4. Klaus Schwab (2017): The Fourth Industrial Revolution. Currency, ISBN 978-1524758868

5. Toro C., Wang W., Akhtar H. (2021): Implementing Industry 4.0. Springer, ISBN 3030672697

6. Acs Z.J., Stam E., Audretsch D.V., O'Connor A. (2017): The lineages of the entrepreneurial ecosystem approach. Small Business Economics, ISSN 0921-898X, https://www.stemecosystems.org.il/wp-content/uploads/ 2020/07/The-lineages-of-the-entrepreneurial-ecosystem-approach.pdf 
7. Autio E., Kenney M., Mustar P., Siegel D., Wright M. (2014): Entrepreneurial innovation: The importance of context. Research Policy, ISSN 0048-7333, Vol. 43, is. 7, pp. 1097-1108, https://doi.org/10.1016/i.respol.2014.01.015

8. Audretsch D., Caiazza R. (2015): Technology transfer and entrepreneurship: cross-national analysis. Journal of Technology Transfer, ISSN 0892-9912, e-ISSN 1573-7047, Vol. 41, pp. 1247-1259, https://link.springer.com/ content/pdf/10.1007/s10961-015-9441-8.pdf

9. Boșcoianu M., Ceocea C., Vladareanu V., Vladareanu L. (2020): Special purpose vehicles for sustainable finance of innovation in Romania - the case of intelligent robotic systems. Periodicals of Engineering and Natural Sciences, ISSN 2303-4521, Vol. 8, no. 3, pp. 1418-1424, http://dx.doi.org/10.21533/pen.v8i3.1518

10. Boșcoianu M., Prelipcean G., Lupan M. (2018): Innovation enterprise as a vehicle for sustainable development - $A$ general framework for the design of typical strategies based on enterprise systems engineering, dynamic capabilities, and option pricing. Journal of Cleaner Production, ISSN 0959-6526, Vol. 172, pp. 3498-3507, https://doi.org/10.1016/i.jclepro.2017.06.120

11. Wiklund J., Shepherd D. (2005): Entrepreneurial orientation and small business performance: a configurational approach. Journal of Business Venturing, ISSN 0883-9026, Vol. 20, is. 1, pp. 71-91, https://doi.org/10.1016/ j.jbusvent.2004.01.001

12. Nicolaou N., Shane S. (2009): Can genetic factors influence the likelihood of engaging in entrepreneurial activity? Journal of Business Venturing, ISSN 0883-9026, Vol. 24, is. 1, pp. 1-22, https://doi.org/10.1016/ j.jbusvent.2007.11.003

13. Audretsch D., Belitski M. (2017): Entrepreneurial ecosystems in cities: establishing the framework conditions. Journal of Technology Transfer, ISSN 0892-9912, e-ISSN 1573-7047, Vol. 42, pp. 1030-1051, https://link.springer.com/article/10.1007/s10961-016-9473-8

14. Prelipcean G., Boșcoianu M. (2020): Risk analysis of a hedge fund oriented on sustainable and responsible investments for emerging markets. Amphitheatre Economic, ISSN 1582-9146, e-ISSN 2247-9104, Vol. 22, is. 55, pp. 653-667, http://www.amfiteatrueconomic.ro/temp/Article 2923.pdf

15. Prelipcean G., Boșcoianu M. (2020): An Innovative Flexible Investment Vehicle Oriented to Sustainability - The Adaptation of Hedge Funds in the Case of Emerging Markets. Proceedings of the ENTRENOVA Conference, pp. 493-503, https://econpapers.repec.org/bookchap/zbwentr20/224715.htm

16. Carayannis E.G., Campbell D.F.J (2010): Triple Helix, Quadruple Helix and Quintuple Helix and How Do Knowledge, Innovation and the Environment Relate To Each Other? A Proposed Framework for a Trans-disciplinary Analysis of Sustainable Development and Social Ecology. International Journal of Social Ecology and Sustainable Development, ISSN 1947-8410, pp. 41-69, DOI:10.4018/jsesd.2010010105, https://www.researchgate.net/ publication/273268696 Triple Helix Quadruple Helix and Quintuple Helix and How Do Knowledge Inno vation and the Environment Relate To Each Other

17. Prelipcean G., Boșcoianu M., Lupan M., Nastase C.E. (2014): Innovative financing solutions based on Venture Capital and Private Equity to support the development of entrepreneurship in Romania. Transformations in Business \& Economics, ISSN 1648-4460, Vol. 13, is. 3C, pp. 331-347, http://www.transformations.knf.vu.lt/ $\underline{33 \mathrm{c} / \text { article/inno }}$ 